MERCATORIA

\title{
Penguji Peraturan Perundang-undangan Tunggal Keniscayaan
}

\author{
Adrian Faridhi * \\ Universitas Lancang Kuning Pekanbaru \\ *Corresponding author: E-mail: $\underline{\text { adrian@unilak.ac.id }}$
}

\begin{abstract}
Abstrak
Pengujian peraturan perundang-undangan di Indonesia dilaksanakan oleh 2 (dua) lembaga negara, yaitu Mahkamah Agung dan Mahkamah Konstitusi, wacana menjadikan pengujian peraturan perundang-undangan kepada lembaga tunggal merupakan langkah maju untuk menyederhanakan kewenangan yang sama pada organ yang sama, hal inilah yang menjadi kajian dari penelitian ini. UUD Tahun 1945 hanya memberikan kewenangan pengujian kepada Mahkamah Agung, namun pasca Amandemen UUD Tahun 1945, baru memberikan kewenangan menguji kepada Mahkamah Konstitusi selain yang telah dimiliki oleh Mahkamah Agung, perkembangan perundang-undangan yang menguraikan perjalanan kewenangan menguji, dimulai dari Undang-undang Kekuasaan Kehakiman, Undang-undang Mahkamah Agung hingga Undang-undang Mahkamah Konstitusi serta Undang-undang Pembentukan peraturan perundang-undangan. Pengujian peraturan perundang-undangan jika dilakukan pada satu lembaga (satu atap) akan membawa berbagai implikasi hukum, hal ini baru dapat terjadi jika ada political will negara untuk mengamandemen UUD Tahun 1945 dan upaya untuk menyederhanakan lembaga negara yang memiliki kewenangan pengujian.
\end{abstract}

Kata Kunci: Kewengan menguji, Mahkamah Agung, Mahkamah Konstitusi

\begin{abstract}
The examiner of legislations in Indonesia was implemented by 2 (two) institutions, Supreme Court and Constitutional Court, the discourse of making the examiner of legislations to single institution is a step forward to simplify the same authority on same institutions, this is the study of this research. The 1945 only given the authority to examine to Supreme Court, but after the amendment of 1945 Constitution, the Constitutional Court also got the authority to examine besides what the Supreme Court already have, the development of legislation which describes the examine authority, starting from judicial power law, Supreme Court law up to Constitutional Court law and the law on the establishment of laws and regulations. The form of examination of legislation if done by one institution (one roof) will resulting a few of law implications, this can only happen if there is a political will of the countryto amend the 1945 constitution and the efforts to simplify the institution which has the authority to examine.
\end{abstract}

Keywords : Examine authority, Supreme Court, Constitutional Court

How to Cite: Faridhi. A., (2017), Penguji Peraturan Perundang-undangan Tunggal Keniscayaan, Mercatoria, 10 (2): 180-196. 


\section{PENDAHULUAN}

Pasca Amandemen Undang-undang

Dasar Negara Republik Indonesia Tahun 1945 (selanjutnya disebut dengan UUD Tahun 1945) telah terjadi perubahan yang mendasar terhadap struktur ketatanegaraan Republik Indonesia, termasuk di dalamnya berupa penghapusan posisi Majelis Permusyawaratan Rakyat (MPR) sebagai lembaga tertinggi negara menjadi lembaga tinggi negara, kemudian terdapatnya lembaga negara baru, yaitu Mahkamah Konstitusi (MK), Dewan Perwakilan Daerah (DPD), Komisi Yudisial (KY) yang disebutkan fungsi dan kewenangan didalam UUD Tahun 1945 pasca Amandemen dari tahun 1999 sampai dengan 2002.

UUD Tahun 1945 setelah Amandemen telah membagi kewenangan terhadap pengujian peraturan perundangundangan kepada Mahkamah Agung dan Mahkamah Konstitusi. Kewenangan Mahkamah Agung terdapat dalam Pasal 24 A UUD Tahun 1945 yang berbunyi:

"Mahkamah Agung berwenang mengadili pada tingkat kasasi, menguji peraturan perundangundangan di bawah undangundang, dan wewenang lainnya yang diberikan oleh undangundang".

Sedangkan kewenangan menguji peraturan perundang-undangan berupa undang-undang terhadap undang-undang dasar yang dimiliki oleh Mahkamah Konstitusi diatur dalam Pasal 24 C UUD Tahun 1945 yang berbunyi:

"Mahkamah Konstitusi berwenang mengadili pada tingkat pertama dan terakhir yang putusannya bersifat final untuk menguji undang-undang terhadap Undangundang Dasar, memutus sengketa kewenangannya diberikan oleh Undang-undang Dasar, memutus pembubaran partai politik, dan memutus perselisihan tentang hasil pemilihan umum".

Berdasarkan Pasal 24 A dan 24 C UUD Tahun 1945, terdapat 2 (dua) lembaga negara yang kewenangannya sama, berupa menguji peraturan perundang-undangan, namun berbeda untuk tingkatannya. Sebagaimana diatur dalam Undang-undang Nomor 12 Tahun 2011 tentang Pembentukan Peraturan Perundang-undangan ${ }^{1}$ membagi peraturan perundang-undangan berdasarkan jenis dan hierarkinya.

Menurut jenis dan hierarki peraturan perundang-undangan, peraturan perundang-undangan dibuat bertingkat dan berjenjang sebagaimana diatur dalam Pasal 7 Ayat (1) Undangundang Nomor 12 Tahun 2011, sebagaimana berbunyi:

"Jenis dan hierarki Peraturan Perundangundangan terdiri atas:

a. Undang-undang Dasar Negara Republik Indonesia Tahun 1945;

b. Ketetapan Majelis Permusyawaratan Rakyat;

c. Undang-undang/Peraturan Pemerintah Pengganti Undangundang;

d. Peraturan Pemerintah;

e. Peraturan Presiden;

f. Peraturan Daerah Provinsi; dan

1Lembaran Negara Republik Indonesia Tahun 2004 Nomor 53. 


\section{Adrian Faridhi, Penguji Peraturan Perundang-undangan Tunggal Keniscayaan}

g. Peraturan

Kabupaten/Kota".

Dengan adanya hierarki peraturan perundang-undangan, maka terlihat batas yang dimiliki oleh Mahkamah Agung dan Mahkamah Konstitusi dalam pengujian peraturan perundang-undangan tersebut. Terdapatnya pemikiran untuk menggabungkan kewenangan menguji kepada satu lembaga negara yang selama ini dibagi kepada 2 (dua) lembaga negara, penulis menganalisa peraturan perundang-undangan sejak Indonesia merdeka tahun 1945 hingga Amandemen UUD Tahun 1945, serta kemungkinankemungkinan hukum yang menyertai dan di lembaga mana sebaiknya kewenangan tersebut diberikan. Konsekuensinya harus ada mekanisme yang dapat menjamin bahwa Undang-undang yang dibuat oleh pembentuk Undang-undang itu tidak bertentangan dengan UUD Tahun $1945^{2}$.

Terdapatnya lembaga negara baru merupakan suatu upaya untuk memurnikan sistem presidensil dan Checks and balances antar lembaga negara, Penulis dalam tulisan ini mengkhususkan tentang posisi Mahkamah Konstitusi dan Mahkamah Agung dalam kewenangannya menguji peraturan perundang-undang berupa menguji undang-undang terhadap UUD Tahun 1945 dan Kewenangan menguji peraturan perundang-undangan dibawah undang-undang, serta bagaimana seandainya Mahkamah Konstitusi dijadikan sebagai lembaga negara tunggal yang dapat menguji peraturan perundang-

\footnotetext{
${ }^{2}$ Tanto Lailam, Konstruksi Pertentangan Norma Hukum dalam Skema Pengujian Undang-undang. Jurnal Konstitusi, Volume 11, Nomor 1, Maret 2014. Hlm.20.
}

undangan baik undang-undang terhadap UUD maupun aturan dibawah undangundang terhadap UUD.

\section{METODE PENELITIAN}

Metode yang digunakan berupa penelitian yuridis normatif dengan menggunakan pendekatan perundangundang (statute approach) digunakan dalam meneliti, mengkaji, menelaah, memahami peraturan perundangundangan yang mengatur mengenai terhadap kewenangan pengujian peraturan perundang-undangan dari awal kemerdekaan hingga pasca Amandemen UUD Tahun 1945.

\section{HASIL DAN PEMBAHASAN}

Kewenangan yang dimiliki oleh Mahkamah Agung dan Mahkamah Konstitusi salah satunya berupa pengujian peraturan perundang-undangan, oleh karena itu defenisi dan pengertian pengujian peraturan perundang-undangan tersebut dapat diartikan sebagai proses untuk menguji peraturan tertulis baik yang dibentuk oleh lembaga negara maupun pejabat yang berwenang yang memiliki kekuatan mengikat secara umum. Oleh karena itu, pengujian peraturan perundang-undangan yang diartikan sebagi suatu proses untuk menguji, akan berkaitan dengan 'siapa' dan 'apa' (objek) dalam proses pengujian peraturan perundang-undangan tersebut. ${ }^{3}$ Pada umumnya istilah toetsingrecht diartikan sebagai hak atau kewenangan

3Zainal Arifin Hoesein, Judicial Review di Mahkamah Agung Republik Indonesia, (Jakarta: PT. Raja Grafido Persada, 2009), hlm. 37. 
untuk menguji atau hak uji ${ }^{4}$. Pengertian tersebut memperjelaskan bahwa toetsingrecht merupakan suatu proses untuk melakukan pengujian atau menguji dan secara harfiah dapat diartikan sebagai kewenangan untuk menguji ${ }^{5}$. Menurut Kamus Indonesia-Belanda karya A. Teeuw, menjelaskan bahwa toetsing diartikan pengujian, toetsen diartikan menguji dan recht diartikan hak atau hukum, sehingga toetsingrecht diartikan sebagai kewenangan untuk menguji atau untuk melakukan pengujian 6 .

$$
\text { Pengertian menguji atau }
$$

melakukan pengujian merupakan proses untuk memeriksa, menilai, dan memutuskan terhadap objeknya. Pemahaman menguji atau melakukan pengujian dalam presfektif teotsingrecht adalah memeriksa, menilai, dan memutuskan terhadap peraturan perundang-undangan yang derajatnya lebih tinggi oleh suatu lembaga negara yang oleh undang-undang dasar/atau oleh undang-undang diberikan kewenangan. ${ }^{7}$ Pengertian toetsingrecht memang cukup luas, sehingga peristilahan yang timbul pun sangat tergantung dengan subjek dan objek dalam pengujian tersebut. Jika dihubungkan dengan subjek, maka

${ }^{4}$ Jimly Asshiddiqie, Model-model Pengujian Konstitusional di Pelbagai Negara, (Jakarta: Konstitusi Press, 2005), hlm. 7.

${ }^{5} \mathrm{M}$. Laica Marzuki, Berjalan-berjalan di Ranah Hukum, (Jakarta: Konstitusi Press, 2005), hlm. 67.

6 A. Teeuw, Kamus Indonesia-Belanda, (Jakarta: Gramedia Pustaka Utama, 2002), hlm. 260 dan 842.

${ }^{7}$ Sri SoemantriMartosoewignjo, HakMenguji Material di Indonesia, (Bandung: Alumni, 1986), hlm. 8. toetsingrecht dapat dilihat pada lembaga kekuasaan negara yudikatif, legislatif dan eksekutif8. Jika hak atau kewenangan menguji diberikan kepada lembaga kehakiman atau hakim, maka hal tersebut disebut judicial review ${ }^{9}$. Akan tetapi, jika kewenangan tersebut diberikan kepada lembaga legislatif, maka istilahnya menjadi legislative review ${ }^{10}$ dan demikian pula jika kewenangan menguji diberikan kepada lembaga eksekutif, maka istilahnya juga menjadi executive review ${ }^{11}$.

Mahkamah Agung dan Mahkamah Konstitusi menjalankan kewenangan sesuai dengan ketentuan yang diatur dalam UUD Tahun 1945. Oleh karena itu, Penulis memulai pembahasan dengan melakukan penelusuran terhadap peraturan perundang-undangan yang mengatur kewenangan menguji yang dimiliki oleh Mahkamah Agung dan Mahkamah Konstitusi.

Penulis membagi pembahasan tentang kewenangan menguji yang dimiliki Mahkamah Agung dan Mahkamah Konstitusi berdasarkan Pelaksanaan Amandemen UUD Tahun 1945.

\section{Tahap Sebelum Amandemen}

Kewenangan menguji peraturan perundang-undangan dalam UUD Tahun 1945 sebelum Amandemen tidak menyebutkan secara jelas hak menguji peraturan perundang-undangan, namun berdasarkan Ketentuan yang diatur dalam Bab IX Pasal 24 dan Pasal 25 UUD Tahun 1945 menjelaskan tentang kekuasaan

${ }^{8}$ Jimly Asshiddiqie, Model-model Pengujian Konstitusional di Pelbagai Negara, Op.Cit., hlm.7.

$$
\begin{aligned}
& { }^{9} \text { Ibid } \\
& { }^{10} \text { Ibid } \\
& { }^{11} \text { Ibid }
\end{aligned}
$$


Mahkamah Agung, badan kehakiman serta susunan kekuasaan badan, sebagaimana bunyi sebagai berikut: Pasal 24 Ayat (1) yang berbunyi " Kekuasaan Kehakiman dilakukan oleh sebuah Mahkamah Agung dan lain-lain badan kehakiman menurut undang-undang" dan bunyi Pasal 24 Ayat (2) sebagai berikut: "Susunan dan kekuasaan badan-badan kehakiman itu diatur dengan undang-undang". Dan Pasal 25 yang berbunyi sebagai berikut: "Syaratsyarat untuk menjadi dan diberhentikan sebagai hakim ditetapkan dengan undangundang".

UUD Tahun 1945 hanya menyebutkan kekuasaan kehakiman yang diselenggarakan oleh Mahkamah Agung dan Badan peradilan dibawahnya, namun membuka peluang untuk menjelaskan kekuasaan kehakiman seperti apa saja yang dimiliki oleh Mahkamah Agung dengan cukup diatur dalam undangundang.

Perintah UUD Tahun 1945 Pasal 24 dan Pasal 25, melahirkan sebuah produk hukum berupa undang-undang pada tahun 1970, yaitu Undang-undang Nomor 14 Tahun 1970 tentang Ketentuan-ketentuan pokok kekuasaan kehakiman. Undangundang Kekuasaan Kehakiman memberikan dasar dalam pelaksanaan pengujian peraturan perundang-undangan di bawah undang-undang yang belum diatur secara jelas dan tegas tentang hak menguji, sebagaimana diatur dalam Pasal 26, sebagai berikut:

(1) Mahkamah Agung berwenang untuk menyatakan tidak sah semua peraturan-peraturan dari tingkat yang lebih rendah dari undang-undang atas alasan bertentangan dengan peraturan perundang-undangan yang lebih tinggi.

(2) Putusan tentang pernyataan tidak sahnya peraturan perundang-undangan tersebut dapat diambil berhubung dengan pemeriksaan dalam tingkat kasasi.

Pencabutan dari peraturan perundangan yang dinyatakan tidak sah tersebut, dilakukan oleh instansi yang bersangkutan. Ketentuan yang diatur dalam Pasal 26 memberikan hak untuk menguji peraturan perundang-undangan di bawah undang-undang kepada Mahkamah Agung berkaitan keabsahan peraturan tersebut. Mahkamah Agung mengambil putusan suatu peraturan perundang-undangan dari tingkatan yang lebih rendah dari undangundang bertentangan dengan peraturan perundang-undangan yang lebih tinggi, dan Mahkamah Agung secara tegas menyatakan bahwa peraturan tersebut adalah tidak sah dan tidak berlaku untuk umum. Namun Mahkamah Agung tidak melakukan pencabutan terhadap peraturan tersebut, melainkan dilakukan oleh instansi yang bersangkutan. Dalam Negara Kesatuan Republik Indonesia hak menguji undang-undang dan peraturan pelaksanaan undang-undang terhadap UUD tidak dimiliki oleh Mahkamah Agung.

Saat pemberlakuan Undang-undang Nomor 14 Tahun 1970, Negara Republik Indonesia belum memiliki mekanisme pengujian peraturan perundangan-undang berupa undang-undang terhadap undangundang dasar. Oleh karena Undangundang Dasar 1945 tidak mengaturnya hak menguji undang-undang terhadap undang-undang dasar, sehingga dengan 
sendirinya hak menguji yang dimiliki Mahkamah Agung diletakkan dalam undang-undang ini. Hak menguji peraturan perundang-undangan diatas undang-undang terhadap Undang-undang dasar apabila hendak diberikan kepada Mahkamah Agung seharusnya merupakan ketentuan Konstitutional yang disebutkan dengan jelas dan tegas dalam UUD Tahun 1945 yang pada saat diundangkan belum diatur secara tegas dalam UUD Tahun 1945.

Dalam rentang 15 (lima belas) tahun setelah Undang-undang Nomor 14 Tahun 1970 tentang Ketentuan-ketentuan pokok kekuasaan kehakiman, baru diundangkan undang-undang khusus yang mengatur Mahkamah Agung, Ketentuan peraturan perundang-undangan yang mengatur tentang Mahkamah Agung diatur lebih lanjut dalam Undang-undang Nomor 14 Tahun 1985 tentang Mahkamah Agung. ${ }^{12}$ Berdasarkan Pasal 31 Ayat (1), (2) dan (3), mengatur sebagai berikut:

(1) Mahkamah Agung mempunyai wewenang menguji secara materiil hanya terhadap peraturan perundang-undangan di bawah ini undang-undang;

(2) Mahkamah Agung berwenang menyatakan tidak sah semua peraturan perundang-undangan dari tingkat yang lebih rendah daripada undang-undang atas alasan bertentangan dengan peraturan perundang-undangan yang lebih tinggi

(3) Putusan tentang pernyataan tidak sahnya peraturan

${ }^{12}$ Lembaran Negara Republik Indonesia Nomor 73 Tahun 1985. perundang-undangan tersebut dapat diambil berhubungan dengan pemeriksaan dalam tingkat kasasi.

Jika dianalisa Penjelasan yang terdapat didalam Undang-undang Nomor 14 Tahun 1985, pada Pasal 31, sebagai berikut: Ayat (1):

"Pasal ini mengatur hak menguji materiil Mahkamah Agung. Mahkamah Agung berhak menguji peraturan yang lebih rendah daripada undang-undang mengenai sah atau tidaknya suatu peraturan atau bertentangan tidaknya suatu peraturan dengan peraturan perundang-undangan yang lebih tinggi".

Dan Penjelasan Ayat (2), sebagai berikut:

“Apabila Mahkamah Agung menggunakan hak menguji berdasarkan pasal ini, maka Mahkamah Agung mengambil putusan bahwa suatu peraturan perundang-undangan dari tingkatan yang lebih rendah daripada undangundang bertentangan dengan peraturan perundang-undangan yang lebih tinggi dan Mahkamah Agung secara tegas menyatakan bahwa peraturan tersebut tidak sah dan tidak berlaku untuk umum".

Sedangkan untuk Ayat keterangan cukup jelas.

Ketentuan Undang-undang Nomor 14 Tahun 1985, menjelaskan beberapa pokok-pokok perubahan dan pengaturan tentang Mahkamah Agung dalam melaksanakan kewenangan menguji, sebagai berikut: 
a. Kewenangan Mahkamah Agung menguji peraturan perundangundangan dibawah undang-undang berkenaan Sah ataupun tidaknya peraturan perundang-undangan tersebut;

b. Mahkamah Agung sebatas menguji peraturan perundangan sebatas pengujian materil, sedangkan pengujian peraturan perundangundangan dikenal sebagai pengujian materil dan pengujian formal;

c. Ketentuan yang diputus tidak sah dan tidak berlaku secara umum.

Perubahan suasana politik ketatanegaraan dimasa awal pergerakan reformasi, berimbas dengan upaya untuk reformasi hukum dari tingkat tertinggi seperti UUD Tahun 1945, sehingga pada tahun 1999 dalam sejarah Negara Republik Indonesia, UUD Tahun 1945 diamandemen untuk pertama kalinya.

\section{Tahap Sesudah Amandemen}

Pasca Amandemen UUD Tahun 1945, menghasilkan perubahan dalam pengaturan kekuasaan kehakiman, berupa terdapatnya mekanisme pengujian peraturan perundang-undangan baru yaitu pengujian undang-undang terhadap UUD Tahun 1945 yang dimiliki oleh Mahkamah Konstitusi dan terdapatnya Komisi Yudisial (KY), sebagaimana diatur dalam UUD Tahun 1945 Pasca Amandemen.

Berdasarkan UUD Tahun 1945, Mahkamah Agung memiliki kewenangan melakukan pengujian peraturan perundang-undangan di bawah undang-undang berdasarkan Pasal 24A, sebagai berikut:
"Mahkamah Agung berwenang mengadili pada tingkat kasasi, menguji peraturan perundangundangan di bawah undangundang, dan mempunyai wewenang lainnya yang diberikan oleh undang-undang".

Sedangkan bagi Mahkamah Konstitusi kewenangan pengujian peraturan perundang-undangan berupa undang-undang terhadap Undang-undang Dasar, diatur dalam Pasal 24 C Ayat (1) sebagai berikut:

"Mahkamah Konstitusi berwenang mengadili pada tingkat pertama dan terakhir yang putusannya bersifat final untuk menguji undang-undang terhadap Undang-undang Dasar, memutus sengketa kewenangan lembaga negara yang kewenangannya diberikan oleh Undang-undang Dasar, memutus pembubaran partai politik, dan memutus perselisihan tentang hasil pemilihan umum".

Perubahan di dalam UUD Tahun 1945, menjadi dasar dari pelaksanaan pengujian undang-undang terhadap undang-undang dasar, implikasi perubahan tersebut, terdapatnya sebuah lembaga negara baru yang disebut sebagai Mahkamah Konstitusi.

Amandemen UUD Tahun 1945 salah satu hasilnya berupa terdapat 2 (dua) lembaga negara yang memiliki hak menguji peraturan perundang-undangan, berupa Mahkamah Agung dan Mahkamah Konstitusi. Sehingga perubahan terhadap undang-undang pelaksana dari kekuasaan kehakiman harus dilakukan perubahan untuk menyesuaikan dengan perintah 
UUD Tahun 1945. Diundangkannya Undang-undang Nomor 4 Tahun 2004 tentang Kekuasaan Kehakiman sebagai pengganti Undang-undang Nomor 14 Tahun 1970 tentang Kekuasaan Kehakiman. ${ }^{13}$

Pasal 11 Undang-undang Nomor 4 Tahun 2004 memberikan pengaturan berkaitan dengan kewenangan Mahkamah Agung, sebagai berikut:

(1) Mahkamah Agung merupakan pengadilan negara tertinggi dari keempat lingkungan peradilan sebagaimana dimaksud dalam Pasal 10 ayat (2).

(2) Mahkamah Agung mempunyai kewenangan:

a. mengadili pada tingkat kasasi terhadap putusan yang diberikan pada tingkat terakhir oleh pengadilan di semua lingkungan peradilan yang berada di bawah Mahkamah Agung;

b. menguji peraturan perundang-undangan di bawah undang-undang terhadap undang-undang; dan

c. kewenangan lainnya yang diberikan undang-undang.

(3) Pernyataan tidak berlaku peraturan perundang-undangan sebagai hasil pengujian sebagaimana dimaksud pada ayat (2) huruf b, dapat diambil baik dalam pemeriksaan tingkat kasasi maupun berdasarkan permohonan langsung kepada Mahkamah Agung.

(4) Mahkamah Agung melakukan pengawasan tertinggi atas perbuatan pengadilan dalam lingkungan peradilan yang berada di bawahnya berdasarkan ketentuan undangundang.

Sedang pengaturan Mahkamah Konstitusi berkaitan dengan kewenangan yang dimiliki diatur dalam Pasal 12 Undang-undang Nomor 4 Tahun 2004, sebagai berikut:

(1) Mahkamah Konstitusi berwenang mengadili pada tingkat pertama dan terakhir yang putusannya bersifat final untuk :

a. menguji undang-undang terhadap Undang-undang Dasar Negara Republik Indonesia Tahun 1945;

b. memutus sengketa kewenangan lembaga negara yang kewenangannya diberikan oleh Undangundang Dasar Negara Republik Indonesia Tahun 1945;

c. memutus pembubaran partai politik; dan

d. memutus perselisihan tentang hasil pemilihan umum.

(2) Selain kewenangan sebagaimana dimaksud pada ayat (1), Mahkamah Konstitusi wajib memberikan putusan atas pendapat Dewan Perwakilan Rakyat bahwa Presiden dan/atau Wakil Presiden diduga 


\section{Adrian Faridhi, Penguji Peraturan Perundang-undangan Tunggal Keniscayaan}

telah melakukan pelanggaran hukum berupa pengkhianatan terhadap negara, korupsi, penyuapan, tindak pidana berat lainnya atau perbuatan tercela, dan/atau tidak lagi memenuhi syarat sebagai Presiden dan/atau Wakil Presiden.

Hak uji Mahkamah Agung terhadap peraturan perundang-undangan yang lebih rendah dari undang-undang. Hak uji tersebut dapat dilakukan baik terhadap materi muatan ayat, pasal, dan/atau bagian dari peraturan perundangundangan tersebut yang bertentangan dengan peraturan perundang-undangan yang lebih tinggi maupun terhadap pembentukan peraturan perundangundangan tersebut.

Mahkamah Agung sebagai lembaga negara yang diberikan kewenangan oleh UUD Tahun 1945, sehingga pengaturannya dilakukan perubahan dan penyesuaian ditingkat undang-undang, sebelum Amandemen UUD Tahun 1945, diatur dalam Undang-undang 14 Tahun 1985 tentang Mahkamah Agung, setelah itu dilakukan perubahan pertama pada tahun 1999 dengan diundangkannya Undangundang Nomor 35 Tahun 1999 tentang Perubahan Atas Undang-undang Nomor 14 Tahun 1970 tentang Ketentuanketentuan Pokok Kekuasaan Kehakiman. ${ }^{14}$

Perubahan Undang-undang tentang Mahkamah Agung pada tahun 1999 tidak mengubah pengaturan tentang hak menguji yang dimiliki oleh Mahkamah Agung, namun pada tahun 2004 dilakukan perubahan Undang-undang Mahkamah

${ }^{14}$ Lembaran Negara Republik Indonesia Tahun 1999 Nomor 147.
Agung, perubahan ini merupakan konsekuensi dari pelaksanaan Amandemen UUD Tahun 1945 dan perubahan terhadap Undang-undang Kekuasaan Kehakiman yang baru.

Mahkamah Agung berdasarkan Undang-undang Nomor 4 Tahun 2004 tentang Perubahan Atas Undang-undang Nomor 14 Tahun 1985 tentang Mahkamah Agung, dan perubahan Pasal 31, sebagai berikut:

(1) Mahkamah Agung mempunyai wewenang menguji peraturan perundang-undangan di bawah undang-undang terhadap undang-undang.

(2) Mahkamah Agung menyatakan tidak sah peraturan perundangundangan di bawah undangundang atas alasan bertentangan dengan peraturan perundangundangan yang lebih tinggi atau pembentukannya tidak memenuhi ketentuan yang berlaku.

(3) Putusan mengenai tidak sahnya peraturan perundang-undangan sebagaimana dimaksud pada Ayat (2) dapat diambil baik berhubungan dengan pemeriksaan pada tingkat kasasi maupun berdasarkan permohonan langsung pada Mahkamah Agung.

(4) Peraturan perundang-undangan yang dinyatakan tidak sah sebagaimana dimaksud pada Ayat (3) tidak mempunyai kekuatan hukum mengikat.

(5) Putusan sebagaimana dimaksud pada Ayat (3) wajib dimuat dalam Berita Negara Republik 
Indonesia dalam jangka waktu paling lambat 30 (tiga puluh) hari kerja sejak putusan diucapkan.

Mahkamah Konstitusi yang merupakan lembaga negara yang lahir pasca Amandemen UUD Tahun 1945, berdiri berdasarkan Undang-undang Nomor 24 Tahun 2003 tentang Mahkamah Konstitusi ${ }^{15}$, yang menjelaskan kewenangan yang dimiliki oleh Mahkamah Konstitusi, sebagaimana diatur Pasal 10 Ayat (1), sebagai berikut: Menguji undangundang terhadap Undang-undang Dasar Negara Republik Indonesia Tahun 1945;

Pengujian undang-undang terhadap UUD Tahun 1945 merupakan hal yang baru untuk ketatanegaraan Republik Indonesia, oleh karena itu, dalam praktek Mahkamah Konstitusi selalu berkembang seiring dengan perubahan Undang-undang Mahkamah Konstitusi ataupun berkembang dengan putusan-putusan Mahkamah Konstitusi.

Dalam hal ini sebagai diatur dalam Pasal 50 Undang-undang Nomor 24 Tahun 2003, sebagai berikut: "Undang-undang yang dapat dimohonkan untuk diuji adalah undang-undang yang diundangkan setelah perubahan Undang-undang Dasar Negara Republik Indonesia Tahun 1945".

Pasal 50 Undang-undang Nomor 24 Tahun 2003 telah putus oleh Mahkamah Konstitusi dengan Putusan Nomor 066/PUU-II/2004 yang menyatakan Pasal 50 tidak mempunyai kekuatan hukum yang mengikat. Mahkamah Konstitusi sebagaimana diamanatkan oleh UUD Tahun 1945 untuk menguji undang-

${ }^{15}$ Lembaran Negara Republik Indonesia Tahun 2003 Nomor 98. undang terhadap UUD 1945 sebelum maupun sesudah Amandemen UUD Tahun 1945.

\begin{tabular}{lcr}
\multicolumn{2}{c}{ Undang-undang } & Mahkamah \\
Konstitusi & mengatur & mekanisme \\
pengujian & peraturan & perundangan- \\
undangan & berupa & undang-undang
\end{tabular}
terhadap UUD, prosedur pengujian hingga putusan terhadap pengujian peraturan perundang-undangan, sebagaimana diatur dalam Pasal 50 sampai dengan Pasal 60 Undang-undang Mahkamah Konstitusi yang sebagaian pasal dan ayatnya sudah dibatalkan oleh Putusan Mahkamah Konstitusi ataupun oleh Perubahan Undang-undang Mahkamah Konstitusi.

Mahkamah Konstitusi dalam melaksanakan kewenangannya menguji peraturan perundang-undangan membuat Peraturan Mahkamah Konstitusi sebagai peraturan yang mengatur teknis dan Hukum Acara Mahkamah Konstitusi. Terdapatnya Ketentuan yang diatur dalam Pasal 55 Undang-undang Mahkamah Konstitusi, sebagai berikut:

"Pengujian peraturan perundangundangan di bawah undangundang yang sedang dilakukan Mahkamah Agung wajib dihentikan apabila undangundang yang menjadi dasar pengujian peraturan tersebut sedang dalam proses pengujian Mahkamah Konstitusi sampai ada putusan Mahkamah Konstitusi".

Berdasarkan ketentuan Pasal 55 di atas, pembuat undang-undang membuat suatu solusi pada suatu keadaan yang mungkin terjadi, undangundang yang sedang diuji di Mahkamah Konstitusi, menjadi dasar untuk menguji peraturan perundang- 
undangan dibawah yang diuji di Mahkamah Agung. Hal ini akan mempengaruhi kepastian hukum bagi pencari keadilan. Namun demikian, sampai saat ini pilihan politik negara bahwa tetap membedakan berdasarkan pengujian peraturan perundanganundangan berdasarkan tingkatan.

Ketentuan berupa kewenangan menguji yang dimiliki oleh Mahkamah Agung ditegaskan dalam Undangundang Nomor 48 Tahun 2009 tentang Kekuasaan kehakiman ${ }^{16}$ Pasal Pasal 20 Ayat (2) dan Ayat (3), sebagai berikut:

Ayat (2), Mahkamah Agung berwenang:

a. mengadili pada tingkat kasasi terhadap putusan yang diberikan pada tingkat terakhir oleh pengadilan di semua lingkungan peradilan yang berada di bawah Mahkamah Agung, kecuali undang-undang menentukan lain;

b. menguji peraturan perundangundangan di bawah undangundang terhadap undangundang; dan

c. kewenangan lainnya yang diberikan undang-undang.

Ayat (3), Putusan mengenai tidak sahnya peraturan perundangundangan sebagai hasil pengujian sebagaimana dimaksud pada ayat (2) huruf b dapat diambil baik berhubungan dengan pemeriksaan pada tingkat kasasi maupun berdasarkan

16Lembaran Negara Republik Indonesia Tahun 2009 Nomor 157. permohonan langsung pada

Mahkamah Agung.

Untuk mendapatkan pemahaman yang kuat tentang hak menguji, berikut akan diuraikan tentang pengujian peraturan perundangan-undangan. Pengujian peraturan perundang-undangan secara terminologi bahasa terdiri dari perkataan pengujian dan peraturan perundang-undangan. Pengujian berasal dari akar kata uji yang memiliki arti percobaan untuk mengetahui mutu sesuatu, sehingga pengujian diartikan sebagai proses, cara, perbuatan, menguji. ${ }^{17}$ Sedangkan peraturan perundangundangan diartikan sebagai peraturan tertulis yang memuat norma hukum yang mengikat secara umum dan dibentuk atau ditetapkan oleh lembaga negara atau pejabat yang berwenang melalui prosedur yang ditetapkan dalam peraturan perundang-undangan ${ }^{18}$.

Pengertian toetsingrecht dalam presfektif judicial review dapat diartikan sebagai toetsingrecht dalam arti sempit atau uji judicial yang subjeknya tertentu, yaitu lembaga kekuasaan kehakiman dan objeknya tertentu juga, yaitu peraturan perundang-undangan yang bersifat mengatur (regels). Dengan demikian, dapat dibedakan dengan jelas bahwa toetsingrecht dalam presfektif judicial review, legislative review dan excecutive review dilihat dari segi subjeknya.

\footnotetext{
17Departemen Pendidikandan Kebudayaan RI, Kamus Besar Bahasa Indonesia, Edisi Kedua, (Jakarta: Balai Pustaka, 1996), hlm.1096-1097.

${ }^{18}$ Lihat Pasal 1 Angka 2 Undang-undang Nomor 12 Tahun 2011 yang diundangkan tanggal 12 Agustus 2011 dalam Lembaran Negara RI Tahun 2011 Nomor 82 dan Tambahan Lembaran Negara RI Nomor 5234.
} 
Demikian pula dalam segi objeknya, maka toetsingrecht dalam presfektif judicial review objek yang diuji adalah peraturan perundang-undangan yang bersifat mengatur ${ }^{19}$.

Konsep toetsingrecht dalam arti judicial review (selanjutnya disebut judicial review) merupakan bagian dari prinsip kontrol secara judicial atas produk peraturan perundang-undangan agar tidak bertentangan dengan norma hukum secara hierarkis ${ }^{20}$. Judicial review dapat dilakukan, manakala prinsip kekuasaan negara menganut pemisahan kekuasaan atau separation of power dan checks and balances $^{21}$. Kedua asas ini memungkinkan adanya keseimbangan posisi dan kekuasaan cabang-cabang kekuasaan negara seperti lembaga legislatif, eksekutif dan yudikatif dapat berjalan secara horizontal, dan memungkinkan masingmasing cabang kekuasaan negara tersebut

${ }^{19}$ Zainal Arifin Hoesein, Judicial Review di Mahkamah Agung Republik Indonesia, Op.Cit., hlm.40-41.

20Ibid.,hlm.41.

${ }^{21}$ Donal P. Kommers, Cross-National Comparations of Constitutional Court Toward a Theory of Judicial Review, Paper - presented at the annual meeting of the American Political Science Association, (Los Angles, Calif, September 11, 1970) dalam Henry J. Abraham, The Judicial Process-An Introductory of the Court of the United States, England, and France, Third Edition Revised and enlarged (London: Oxford University Press, 1975),hlm. 281-283 mengambarkan bahwa judicial review sebagai doktrin hukum dapat dilaksanakan karena lima faktor, yakni(1) regime stability; (2) a competitive political party system; (3) significant horizontal power distribution; (4) a strong tradition of judicial independent; and (5) a high degree of political freedom, dalam Zainal Arifin Hoesein, Judicial Review di Mahkamah Agung Republik Indonesia, Ibid., hlm.41. dapat melakukan fungsinya sesuai yang diatur dan ditetapkan dalam undangundang dasar dan/atau undang-undang22.

Judicial review merupakan suatu proses untuk menguji konstitusionalitas suatu produk hukum badan legislatif atau badan eksekutif. Ini mengindikasikan tiga elemen pokok tentang judicial review, yaitu pertama, badan yang melaksanakan judicial review adalah badan/lembaga kekuasaan kehakiman, kedua, adanya unsur pertentangan antara norma hukum yang derajatnya di bawah dengan norma hukum yang derajatnya di atas; dan ketiga, objek yang diuji adalah lingkup tindakan atau produk hukum badan legislatif dan ketetapan kepala eksekutif ${ }^{23}$.

Kewenangan untuk melaksanakan judicial review adalah kewenangan badan kekuasaan kehakiman yang diberi kewenangan khusus untuk itu oleh undang-undang dasar dan/atau undangundang untuk menguji tingkat konstitusionalitas atau keabsahan suatu peraturan perundang-undangan terhadap peraturan perundang-undangan yang secara hierarkis derajatnya lebih tinggi ${ }^{24}$.

Istilah judicial review terbatas penggunaanya kepada proses uji perundang-undangan yang dilakukan oleh lembaga peradilan. Lalu kenapa terdapat pembagian judicial review, constitutional review dan judicial constitutional review. Constitutional review digunakan secara

${ }^{22}$ Ibid.,hlm.41.
${ }^{23}$ Ibid.,hlm.41-42.
${ }^{24}$ A.P.Le Sueur dan JW Herberg, Introduction to the Grounds of Judicial Review, dalam Constitutional and Adiministrative Law, (London, British Library Cataloguing in Publication Data, 1995) hlm.204, dalam Zainal Arifin Hoesein, Ibid.,hlm.42. 
umum terhadap proses uji konstitusionalitas produk perundangundangan yang berada di bawah konstitusi yang dilakukan oleh lembaga legislatif (seperti oleh MPR pada masa Orde Baru) ataupun oleh lembaga peradilan, bahkan oleh sebuah lembaga khusus yang ditunjuk untuk melakukan tugas uji constitutional tersebut (seperti Dewan Konstitusi di Prancis). Istilah khusus judicial constitutional review baru dapat digunakan dalam membicarakan proses uji konstitusionalitas yang dilakukan oleh lembaga peradilan saja. ${ }^{25}$

Objek pengujian yang diuraikan disini adalah objek norma hukum yang diuji $^{26}$. Secara umum, istilah pengujian atau peninjauan kembali itu dalam bahasa inggrisnya adalah review, yang apabila dilakukan oleh hakim, disebut judicial review ${ }^{27}$. Jenis review dapat dibedakan berdasarkan objek yang diuji. Pembagian objek judicial review ini tidak jauh berbeda dengan pembagian pengujian produk hukum secara umum (toetsingrecht), yaitu (a) formele toetsingrecht dan (b) materiele toetsingrecht. ${ }^{28}$ Sehingga dalam judicial reviewterdapat pula jenis formiil judicial review dan materiil judicial review. Hal tersebut dikarenakan kaidah hukum juga terbagi antara kaidah formil dan materil yang menurut Jimly Asshiddiqie, paralel

${ }^{25}$ Muchamad Ali Safa'at, "Toetsingsrecht", "Judicial Review", "Constitutional Review", dalam Majalah Konstitusi-Berita Mahkamah Konstitusi, No.14 januari-Februari 2006, h. 47.

26Jimly Asshiddiqie, Hukum Acara Pengujian Undang-undang, (Jakarta: Sinar Grafika, cetakan pertama, Mei 2010), hlm.16.

${ }^{27} \mathrm{Ibid}$.,hlm.18.

${ }^{28}$ Sri Soemantri, Hak Menguji Material Di Indonesia., Op.Cit.,hlm. 5-6. dengan pembedaan antara hukum materill dan hukum formill. Hukum materiil atau substantive law mengatur mengenai substansi normanya, sedangkan hukum formil atau procedural law mengatur mengenai prosedur penegakan norma hukum materiil itu. ${ }^{29}$

Terhadap hak uji materil, Sri Soemantri, memberikan garis bawah bahwa pengujian tersebut adalah suatu wewenang untuk menyelidiki dan kemudian menilai, apakah suatu peraturan perundang-undangan isinya sesuai atau bertentangan dengan peraturan yang lebih tinggi derajatnya, serta apakah suatu kekuasan tertentu (verordenende macht) berhak mengeluarkan suatu peraturan tertentu ${ }^{30}$. Oleh karenanya objek judicial review juga terbagi dua, yaitu pertama, objek yang berupa isi (bunyi pasal-pasal) dari sebuah peraturan perundang-undangan (materiel law) dan kedua, objek yang berupa prosedur pembentukan peraturan perundang-undangan (formal law). Jika sebuah permohonan pengujian memohonkan uji terhadap dua objek tersebut, objek materil maupun objek formil, maka yang harus dibuktikan oleh hakim semestinya adalah objek formilnya terlebih dahulu. Hal itu dikarenakan secara logika hukumnya, jika objek formilnya atau prosedur pembentukan sebuah peraturan perundang-undangan telah bertentangan dengan aturan yang lebih tinggi maka otomatis seluruh

${ }^{29}$ Jimly Asshiddiqie, Pokok-Pokok Hukum Tata Negara Indonesia-Pasca Reformasi, PT. Bhuana Ilmu Populer (BIP), Jakarta, 2007, hlm.579.

${ }^{30}$ Sri Soemantri, Hak Menguji Material Di Indonesia., Op.Cit.,hlm. 5-6. 
ketentuan peraturan perundangundangan (termasuk objek materil) tersebut dianggap telah bertentangan dengan peraturan hukum yang lebih tinggi.

Melihat kondisi yang demikian, dapat dipahami bahwa dalam memutuskan sebuah perkara, hakim Mahkamah Konstitusi semestinya tidak melihat teks UUD semata melainkan "jiwa" dari teks tersebut dan menyesuaikannya dengan kehendak konstitusional generasi kekinian dari bangsa Indonesia. Kalau Hakim Mahkamah Konstitusi tidak melakukan itu yang ada bukanlah judicial creativity melainkan judicial terrorism. Sebagaimana dikatakan oleh Satjipto Rahadjo ludah dari 9 (Sembilan) Hakim Mahkamah Konstitusi dapat menjadi "api" (Kompas, 5/01/09) jika tidak memperhatikan semangat keadilan sesungguhnya. ${ }^{31}$

Semua produk perundangundangan yang lahir adalah melalui proses politik. Para anggota legislatif dan eksekutif adalah perwakilan dari partai politik dan DPD sehingga dalam setiap proses pembuatan draft dan RUU yang selalu memiliki kepentingan politis. Di sisi lain undang-undang adalah produk hukum yang harus ditaati oleh seluruh warga negara Indonesia. Sebaliknya kedudukan dan kekuasaan politik harus mendapat

${ }^{31}$ Pusat Studi Konstitusi Fakultas Hukum Universitas Andalas Dan Mahkamah Konstitusi, Perkembangan Pengujian Perundang-Undangan Di Mahkamah Konstitusi (Dari Berpikir Hukum Tekstual ke Hukum Progresif), Hasil Penelitian Agustus-Oktober 2010 legitimasi hukum agar dapat dinyatakan berwenang atas nama negara dan rakyat. ${ }^{32}$ Jimly Asshiddiqie membagi dua jenis judicial review, yaitu: (1) concreate norm review dan (2) abstact norm review. ${ }^{33}$ Concrete norm review tersebut dapat berupa;

1. Pengujian terhadap norma konkrit terhadap keputusankeputusan yang bersifat administratif (beschikking), seperti dalam PTUN (peradilan tata usaha negara);

2. Pengujian terhadap norma konkrit dalam jenjang peradilan umum, seperti pengujian putusan peradilan tingkat pertama oleh peradilan banding, pengujian putusan peradilan banding oleh peradilan kasasi serta pengujian putusan peradilan kasasi oleh Mahkamah Agung. ${ }^{34}$

Mekanisme pengujian konstitusionalitas undang-undang adalah pengujian mengenai nilai konstitusionalitas undang-undang itu, baik dari segi formil ataupun materiil. Oleh karena itu, pada tingkat pertama, pengujian konstitusionalitas itu haruslah dibedakan dari pengujian legalitas. Mahkamah Konstitusi melakukan pengujian konstitusionalitas, sedangkan Mahkamah Agung melakukan pengujian legalitas, bukan pengujian

32Franky Butar Butar, Mengoptimalkan Kewenangan Mahkamah Konstitusi(Opini),Jakarta: Berita Mahkamah Konstitusi, Nomor 16, Edisi JuliAgustus 2006), hlm.9.

33Jimly Asshiddiqie, Pokok-Pokok Hukum Tata Negara Indonesia-Pasca Reformasi Op.Cit., hlm.590.

${ }^{34}$ Ibid 
konstitusionalitas. ${ }^{35}$ Objek yang diuji oleh Mahkamah Agung berupa peraturan dibawah undang-undang, sedangkan Mahkamah Konstitusi hanya menguji undang-undang saja, bukan peraturan lain yang tingkatannya berada di bawah undang-undang.

Mahkamah Konstitusi berwenang menguji undang-undang terhadap UUD Tahun 1945, dan Mahkamah Agung berwenang menguji peraturan perundangundangan berupa undang-undang ke bawah berdasarkan hierarki peraturan perundang-undangan. Untuk menilai atau menguji konstitusionalitas suatu undangundang, menurut Jimly Asshiddiqie, dapat mempergunakan beberapa alat pengukur atau penilai, yaitu:

1. Naskah undang-undang dasar yang resmi tertulis, beserta

2. Dokumen-dokumen tertulis terkait erat dengan naskah undang-undang dasar itu, seperti risalah-risalah, keputusan dan ketetapan MPR, undang-undang tertentu, peraturan tata tertib, dan lainlain; serta

3. Nilai-nilai konstitusi yang hidup dalam praktik ketatanegaraan yang telah dianggap sebagai bagian yang tak terpisahkan dari keharusan dan kebiasaan dalam penyelenggaraan kegiatan bernegara; dan

4. Nilai-nilai yang hidup dalam kesadaran kognitif rakyat serta kenyataan perilaku politik dan

35Jimly Asshiddiqie, Hukum Acara Pengujian Undang-undang, Loc.Cit.,hlm.4. hukum warga negara yang dianggap sebagai kebiasaan dan keharusan-keharusan yang ideal dalam perikehidupan berbangsa dan bernegara. ${ }^{36}$

Dalam ilmu perundang-undangan, undang-undang biasanya ditinjau dari dua sudut pandang. Pertama, undang-undang ditinjau dari aspek materiil (wet in materiele zin), yaitu melihat pada segi isi , materi, atau substansi undang-undang. Kedua, undang-undang dilihat dari aspek formil (wet in formele zin), yaitu meninjau dari segi bentuk dan pembentukkannya. ${ }^{37}$ Pengertian undang-undang dalam arti materiil itu (wet in materiele zin) dan dalam arti formil (wet in formele zin) dapat pula dilihat sebagai perbedaan cara pandang atau perspektif. ${ }^{38}$

Dengan keterangan diatas tentang pengujian peraturan perundanganundangan yang dilaksanakan oleh Mahkamah Agung dan Mahkamah Konstitusi, bisa saja dilaksanakan oleh satu lembaga negara, dan lembaga yang tepat berupa Mahkamah Konstitusi. Hal ini baru dapat diterapkan jika UUD Tahun 1945 dilakukan perubahan dan memasukan kewenangan menguji khusus kepada Mahkamah Konstitusi.

Berikut kemungkinankemungkinan yang timbul jika Mahkamah Konstitusi diberikan kewenangan sebagai lembaga negara tunggal yang melakukan pengujian peraturan perundangan-

36jimly Asshiddiqie, Hukum Acara Pengujian Undang-undang ,Op.Cit., hlm.6.

${ }^{37}$ Jimly Asshiddiqie, Perihal Undangundang, Loc. Cit, hlm.23-24.

38Ibid., hlm. 24 
undangan (Judicial review), sebagai berikut:

a. Kewenangan Mahkamah Agung dalam memutus perkara kasasi, dibatasi untuk tidak dapat membatalkan norma, karena kewenangan pembatalan norma telah diberikan kepada lembaga khusus, sehingga tidak ada dualisme lembaga yang melaksanakan judicial review;

b. Andai lembaga tersebut adalah Mahkamah Konstitusi, tentu dibutuhkan penambahan jumlah Hakim Konstitusi, karena kebutuhan Sumber Daya Manusia (SDM) yang banyak mengingat perkara yang akan bertambah;

c. Pelaksanaan pengujian paraturan perundangan satu atap (di Mahkamah Konstitusi) akan membuat putusan yang dihasilkan dapat lebih sistematis dan tidak menimbulkan kendala dalam penerapannya.

\section{SIMPULAN}

Pengujian peraturan perundangundangan jika dilakukan pada satu lembaga (satu atap) akan membawa berbagai implikasi hukum, hal ini baru dapat terjadi jika ada political will negara untuk mengamandemen UUD Tahun 1945 kembali, hal ini dapat menata kembali secara kelembagaan kekuasaan kehakiman, khususnya tentang pengujian peraturan perundang-undangan.

Pengabungan kewenangan menguji yang saat ini dimiliki oleh Mahkamah Agung dan Mahkamah Konstitusi merupakan suatu pemikiran yang progresif, hal ini Penulis sebut sebagai upaya untuk menyederhanakan lembaga negara yang melakukan pengujian. Pengujian Konstitusionalitas yang bersumber kepada konstitusi (UUD Tahun 1945), sehingga seluruh peraturan perundang-undangan tidak boleh bertentangan dengan UUD Tahun 1945 sesuai dengan prinsip jenis dan hierarki perundangan-undangan yang diatur dalam Undang-undang Nomor 12 Tahun 2011.

\section{DAFTAR PUSTAKA}

A. Teeuw, 2002. Kamus Indonesia-Belanda, Jakarta: Gramedia Pustaka Utama.

Departemen Pendidikan dan Kebudayaan RI, 1996. Kamus Besar Bahasa Indonesia, Edisi Kedua, Jakarta: Balai Pustaka.

Franky Butar Butar, 2006. Mengoptimalkan Kewenangan Mahkamah Konstitusi(Opini), Jakarta: Berita Mahkamah Konstitusi, Nomor 16, Edisi Juli-Agustus 2006.

Jimly Asshiddiqie, 2005. Model-model Pengujian Konstitusional di Pelbagai Negara, Jakarta: Konstitusi Press. 2010. Hukum Acara Pengujian Undang-undang, cetakan pertama Jakarta: Sinar Grafika. 2010. Pokok-Pokok Hukum Tata Negara Indonesia-Pasca Reformasi, Jakarta: PT. Bhuana Ilmu Populer (BIP).

Muchamad Ali Safa'at, 2006. "Toetsingsrecht", "Judicial Review", "Constitutional Review", dalam Majalah Konstitusi-Berita Mahkamah Konstitusi, No.14 JanuariFebruari 2006.

Laica Marzuki, 2005. Berjalan-berjalan di Ranah Hukum, Jakarta: Konstitusi Press.

Pusat Studi Konstitusi Fakultas Hukum Universitas Andalas Dan Mahkamah Konstitusi, 2010. Perkembangan Pengujian Perundang-Undangan Di Mahkamah Konstitusi (Dari Berpikir Hukum Tekstual ke Hukum Progresif), Hasil Penelitian Agustus-Oktober 2010. 
Republik Indonesia, Undang-undang Nomor 14 Tahun 1970 tentang Ketentuanketentuan pokok kekuasaan kehakiman.

Republik Indonesia, Undang-undang Nomor 14 Tahun 1985 tentang Mahkamah Agung.

Republik Indonesia, Undang-undang Nomor 35 Tahun 1999 tentang Perubahan Atas Undang-undang Nomor 14 Tahun 1970 Tentang Ketentuan-Ketentuan Pokok Kekuasaan Kehakiman.

Republik Indonesia, Undang-undang Nomor 24 Tahun 2003 tentang Mahkamah Konstitusi

Republik Indonesia, Undang-undang Nomor 4 Tahun 2004 tentang Kekuasaan Kehakiman sebagai pengganti Undangundang Nomor 14 Tahun 1970 tentang Kekuasaan Kehakiman.

Republik Indonesia, Undang-undang Nomor 48 Tahun 2009 tentang Kekuasaan Kehakiman.

Republik Indonesia, Undang-undang Nomor 12 Tahun 2011 tentang Pembentukan Peraturan Perundang-undangan.

Sri Soemantri Martosoewignjo, 1986. Hak Menguji Material di Indonesia, Bandung: Alumni.

Tanto Lailam, 2014. Konstruksi Pertentangan Norma Hukum dalam Skema Pengujian Undang-undang. Jurnal Konstitusi, Volume 11, Nomor 1.

Zainal Arifin Hoesein, 2009. Judicial Review di Mahkamah Agung Republik Indonesia, Jakarta:PT. Raja Grafido Persada. 